\section{ADVANCES IN}

PSYCHIATRY \& NEUROLOGY

POSTEPY

Psychiatrii i Neurologi

\title{
Real-life anti-smoking practices among Polish neurologists
}

\section{Prakłyki antynikotynowe wśród polskich neurologów}

Correspondence to/Adres do korespondencji:

Dr. Halina Sienkiewicz-Jarosz

$1^{\text {st }}$ Department of Neurology

Institute of Psychiatry and Neurology

9 Sobieskiego St.

02-957 Warsaw, Poland

e-mail: jarosz@ipin.edu.pl

Submitted/Otrzymano: 09.03.2021

Accepted/Przyjęto do druku: 07.05.2021

\author{
Magdalena Konopko' (D), Przemysław Bieńkowski² (D), \\ Marcin Wojnar ${ }^{2} \mathbb{D}$, Jerzy Samochowiec ${ }^{3} \mathbb{D}$, \\ Danuta K. Ryglewicz' (D), Halina Sienkiewicz-Jarosz' (D)
}

$\left.{ }^{1}\right]^{\text {st }}$ Department of Neurology, Institute of Psychiatry and Neurology, Warsaw, Poland
${ }^{2}$ Department of Psychiatry, Medical University of Warsaw, Poland

${ }^{3}$ Department of Psychiatry, Pomeranian University of Medicine, Szczecin, Poland

\begin{abstract}
Purpose: The aim of the present study was to assess attitudes of Polish neurologists towards cigarette smoking and their real-life anti-smoking practices.

Methods: A study questionnaire was constructed, and distributed among Polish neurologists ( $n=101 ; 73 \%$ females). More than two thirds $(70 \%)$ of the study group worked in in-patient neurological wards with separate stroke units.

Results: Seventy five percent of the study group documented the smoking status of their patients in medical files. Two thirds of the study group collected data on patient's cigarette smoking during each visit. Only $54 \%$ and $22 \%$ of study participants routinely assessed the severity of tobacco dependence and diagnosed tobacco dependence according to the ICD-10 criteria, respectively. Two thirds of physicians declared routinely using any anti-smoking intervention, but only $12 \%$ used the recommended 5'A (Ask, Advice, Assess, Assist, Arrange) model of behavioral intervention and only 11\% introduced Evidence Based Medicine (EBM)-supported pharmacotherapy. The vast majority of study participants $(80 \%)$ did not try to increase their professional skills in anti-smoking interventions.

Conclusions: Real-life anti-smoking practices among Polish neurologists are generally unsatisfactory and do not follow EBM-based guidelines. The low percentage of neurologists who diagnose and treat nicotine dependence may negatively impact the efficacy of secondary stroke prevention in Poland.
\end{abstract}

Key words: smoking, intervention, stroke, attitudes, neurologists.

\section{Streszczenie}

Cel: Celem pracy była ocena postaw polskich neurologów wobec palenia papierosów przez pacjentów z chorobami neurologicznymi, a szczególnie po udarze mózgu, i ich rzeczywistych praktyk dotyczących diagnozowania i leczenia uzależnienia od nikotyny. Metody: Badanie kwestionariuszowe przeprowadzono wśród aktywnych zawodowo neurologów ( $n=101 ; 73 \%$ kobiet). Ponad dwie trzecie (70\%) badanej grupy pracowało na oddziałach neurologicznych mających oddziały lub pododdziały udarowe.

Wyniki: Spośród badanej grupy 75\% dokumentowało status palenia swoich pacjentów w dokumentacji medycznej. Dwie trzecie badanej grupy zbierało dane dotyczące palenia papierosów podczas każdej wizyty. Tylko 54\% i 22\% uczestników badania rutynowo oceniało nasilenie uzależnienia od palenia tytoniu i diagnozowało uzależnienie według kryteriów ICD-10. Dwie trzecie lekarzy zadeklarowało rutynowe stosowanie jakiejkolwiek interwencji antynikotynowej, ale tylko $12 \%$ stosowało zalecany model interwencji behawioralnej 5'A (ask - pytaj, advice - poradź, assess - oceń, assist - pomóż, arrange - planuj), a 11\% zalecało farmakoterapię opartą na dowodach naukowych (evidence based medicine - EBM). Zdecydowana większość uczestników badania (80\%) nie próbowała podnosić swoich umiejętności zawodowych w zakresie interwencji antynikotynowych.

Wnioski: Rzeczywiste praktyki antynikotynowe wśród polskich neurologów nie są zadowalające i nie są zgodne z wytycznymi opartymi na EBM. Biorąc pod uwagę ryzyko związane z kontynuacją palenia po udarze, niski odsetek lekarzy neurologów diagnozujących i leczących uzależnienie od nikotyny może negatywnie wpływać na skuteczność prewencji wtórnej udaru mózgu w Polsce. Słowa kluczowe: palenie, interwencja, udar, postawy, neurolodzy. 


\section{INTRODUCTION}

The chronic use of tobacco products, including cigarette smoking, is one of the leading causes of cancer and cardiovascular morbidity worldwide. Cigarette smoking is also recognized as an important risk factor contributing to first-in-a-lifetime or recurrent stroke. The risk of stroke is increased from 2 to 4 times in current smokers as compared to nonsmokers or subjects who gave up smoking more than 10 years ago $[1,2]$.

It has been shown repeatedly that the vast majority of chronic cigarette smokers declare they would be willing to quit smoking [3, 4]. For example, the National Health Survey (Project WOBASZ) indicated that more than $80 \%$ of Polish smokers would like to quit [5]. It is worth noting that acute illness and hospitalization significantly increases individual motivation to quit smoking [6], and that hospitalization secondary to tobacco-related health problems may increase the chance of successful quitting even further $[3,7]$.

The above observations may be referred to stroke survivors. Bienkowski et al. have reported that $100 \%$ of Polish smokers with acute ischemic stroke declared a willingness to quit within the following month [8]. More than two thirds of patients made at least one attempt to quit between stroke onset and their 3-month follow-up visit. The patients reporting stroke as the major reason for quitting were more likely to be abstinent at the follow-up as compared to those indicating other reasons [3].

Healthcare providers, including neurologists, may be major contributors to efforts to reduce cigarette smoking and nicotine dependence in modern societies. Physician's advice significantly increases the number of patients who attempt and succeed in quitting smoking [9]. Introducing evidence-based pharmacotherapy can increase success rates even further $[10,11]$. Given the above, evidence-based guidelines on the diagnosis and treatment of nicotine dependence have been adopted by many medical societies $[9,11,12]$.

Although physicians are uniquely positioned to promote smoking cessation, their real-life attitudes towards cigarette smoking in their patients are influenced by many factors, including professional education and specialty $[13,14]$. While pulmonologists, ENT specialists, and cardiologists declare a high level of interest in the cigarette smoking of their patients, ophthalmologists, infectious disease specialists, and general surgeons may express little interest in patients' smoking habits [15].

Surprisingly little is known about the attitudes towards cigarette smoking and anti-smoking practices of European neurologists. A survey of US and Canadian neurologists has shown that $100 \%$ of vascular neurologists and $96.6 \%$ of general neurologists educate their patients about risks associated with active smoking. A lower percentage of respondents ( $77 \%$ and $59 \%$ of vascular and general neurologists, respectively) declared that they treat nicotine dependence in their patients. Unfortunately, specific anti-smoking practices were not analyzed in the survey [16]. A more recent Dutch study has indicated that most neurologists inform stroke patients about the importance of smoking cessation [17]. The latter study did not address the implementation of diagnostic and smoking cessation techniques recommended in contemporary evidence-based guidelines [20].

The aim of the present study was to describe attitudes of Polish neurologists towards cigarette smoking and to assess their real-life anti-smoking practices. Interestingly, both WHO and European Union anti-smoking initiatives are directed mainly to primary care physicians [18]. Stroke guidelines usually mention smoking as a risk factor for stroke, but rarely address any specific anti-smoking interventions [19]. Thus, in a broader perspective, the aim of the present study was to provide a basis for the development of training platforms specifically designed to address the educational needs of neurologists working with stroke patients.

\section{METHODS}

\section{Questionnaire}

Four authors (M.K., H.S.-J., P.B., M.W.) designed the first version of study questionnaire on physician's perception of smoking-related risks, the attitudes towards cigarette smoking of his/her patients, and anti-smoking practices incorporating well-established guidelines on the diagnosis and treatment of tobacco dependence $[11,18,20]$. The instrument was pilot-tested on a group of neurologists and psychiatrists from the Institute of Psychiatry and Neurology for its clarity and clinical relevance. Their feedback was used to create the final version of the questionnaire.

The questionnaire consisted of the following parts: sociodemographic characteristics of study group (age, gender, specialization, type of health care facility), smoking habits among study participants, perception of etiology and complications of cigarette smoking, and diagnostic and therapeutic practices. Considering anti-smoking practices, neurologists were asked about using the Fagerström Test for Nicotine Dependence [21], the ICD-10 criteria for tobacco dependence [22], brief anti-smoking interventions, and prescribing anti-smoking pharmacotherapy (e.g., nicotine replacement therapy, bupropion, varenicline) [20, 23]. In the last part of the questionnaire, physicians were questioned about their educational needs related to the diagnosis and treatment of tobacco dependence.

The questions regarding diagnostic and therapeutic practices are listed in Table 1 as an example of the questionnaire content. Tables 2-6 reflect the content of other parts of the questionnaire. 
Table 1. Example of questionnaire content - diagnosis and treatment of tobacco dependence $(N=n o, Y=y e s)$

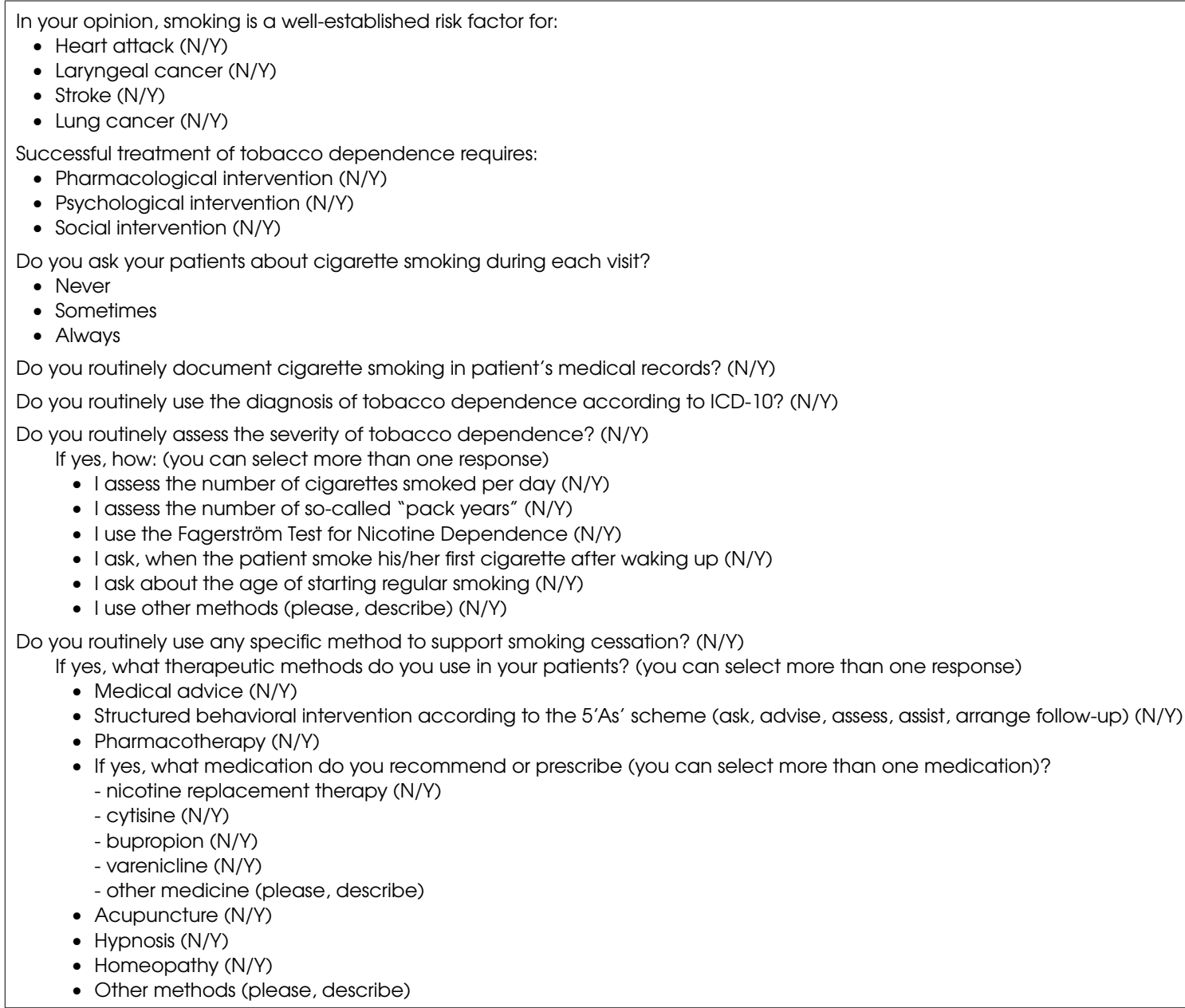

\section{The study group}

Board-certified neurologists were approached during post-graduate courses organized under the umbrella of the National Consultant for Neurology and the Polish Neurological Association in 2015. The subjects received the questionnaire and instruction along with their conference materials. A verbal announcement and instructions were provided before the start of the first educational session.

The questionnaire contained an explicit statement that the participation in the study was voluntary and that the full anonymity of each participant was guaranteed. The response rate was $51 \%$, as $101 / 198$ neurologists gave back completed questionnaires. Table 2 shows basic sociodemographic characteristics of the study group.

\section{Statistical analysis}

The study was exploratory in nature and no formal hypotheses were tested. Hence, descriptive statistics including means, standard deviations (SD), and percentages were used.

\section{Ethics}

According to local Institutional Ethics Committee (EC) at the Institute of Psychiatry and Neurology recommendation, the approval of EC for this non-interventional study was not required.

\section{RESULTS}

\section{Sociodemographic characteristics of the study group}

One hundred and ninety eight neurologists were invited to participate in the study. The final group (50.5\% of the invited subjects) included 101 physicians, 73\% females (for other details, including age groups, see Table 2). Two thirds of the physicians (67\% of the study group) lived in towns with more than 100,000 inhabitants.

More than two thirds (70\%) worked in in-patient neurological wards with separate stroke units, which is typical of the Polish model of stroke care. Fifty four percent of neurologists had contact with more than 20 stroke patients per month (Table 2). 
Real-life anti-smoking practices among Polish neurologists

Praktyki antynikotynowe wśród polskich neurologów

Table 2. Sociodemographic characteristics of study participants $(n=101)$

\begin{tabular}{|l|l|}
\hline Factor & \multicolumn{1}{|c|}{$\begin{array}{c}\text { Proportion } \\
\text { of neurologists (\%) }\end{array}$} \\
\hline \begin{tabular}{l} 
Age \\
\hline$<40$
\end{tabular} & 38 \\
\hline $41-55$ & 34 \\
\hline$>55$ & 28 \\
\hline Females (\%) & 73 \\
\hline \begin{tabular}{l} 
Location of hospital/outpatient clinic \\
\hline Town < 50 000
\end{tabular} \\
\hline Town 50 000-100 000 & 19 \\
\hline Town > 100 000 & 13 \\
\hline Working in hospital/clinic with stroke unit & 65 \\
\hline
\end{tabular}

Table 3. Attitudes towards cigarette smoking among neurologists $(\mathrm{N}=\mathrm{no}, \mathrm{Y}=$ yes $)$

\begin{tabular}{|l|c|}
\hline Item & $\begin{array}{c}\text { Proportion of neurologists } \\
\text { answering „yes” (\%) }\end{array}$ \\
\hline \begin{tabular}{l} 
Cigarette smoking is a: \\
\hline Psychological problem (N/Y)
\end{tabular} & 93 \\
\hline Social problem (N/Y) & 97 \\
\hline Medical problem (N/Y) & 100 \\
\hline \begin{tabular}{l|l|} 
Cigarettes smoking is a well-established risk factor for: \\
\hline Myocardial infarction (N/Y)
\end{tabular} & 98 \\
\hline Laryngeal cancer (N/Y) & 96 \\
\hline Stroke (N/Y) & 96 \\
\hline Lung cancer (N/Y) & 99 \\
\hline
\end{tabular}

Table 4. Diagnostic habits regarding cigarette smoking among neurologists $(N=n o, Y=$ yes)

\begin{tabular}{|l|c|}
\hline Item & Proportion of neurologists answering „yes” (\%) \\
\hline Asking about cigarette smoking during each visit (N/Y) & 68 \\
\hline Cigarette smoking routinely documented in patient's medical records (N/Y) & 75 \\
\hline Tobacco dependence diagnosed according to ICD-10 criteria (N/Y) & 22 \\
\hline Routine assessment of severity of tobacco dependence (N/Y) & 54 \\
\hline \begin{tabular}{l} 
Severity of tobacco dependence assessed preferentially by: \\
\hline Cigarettes per day (N/Y)
\end{tabular} \\
\hline Pack years (N/Y) & 45 \\
\hline FTND* $(N / Y)$ & 25 \\
\hline Time to the first cigarette after awakening (N/Y) & 2 \\
\hline Age of regular smoking initiation (N/Y) & 4 \\
\hline Other $(N / Y)$ & 26 \\
\hline
\end{tabular}

${ }^{*}$ Fagerström Test for Nicotine Dependence

\section{Smoking habits among study participants}

Sixty six percent of physicians were classified as neversmokers, while $14 \%$ and $20 \%$ were classified as currentand former-smokers, respectively.

The mean number of smoking cessation attempts among ever-smokers (the current and former smokers) was $1.5 \pm 1.6$ (range: $1-5$ ). Social, economic, and medical factors were identified as reasons for their own smoking cessation attempts by $35 \%, 44 \%$, and $17 \%$ of ever-smokers, respectively. The majority of ever-smokers (59\%) perceived pharmacotherapy as a primary determinant of success in smoking cessation attempts, while $41 \%$ and $3 \%$ of ever- smokers indicated social support and their own strong will, respectively.

\section{Perception of the etiology of nicotine dependence and complications of cigarette smoking}

In line with the modern view of nicotine dependence, the vast majority of neurologists identified smoking as a multidisciplinary problem with psychological, social, and medical origins (for details, see Table 3). Similarly, the vast majority of subjects correctly perceived smoking as a well-established risk factor for cancer and cardiovascular disorders.

\section{Diagnostic habits}

Seventy five percent of the study group declared that they routinely document the smoking status of their patients in medical records (Table 4). Two thirds of the neurologists reported that they ask about cigarette smoking during each visit. Only $54 \%$ and $22 \%$ of study participants routinely assessed the severity of tobacco dependence and diagnosed tobacco dependence according to the ICD-10 criteria, respectively. The number of cigarettes smoked per day was a preferred measure to assess the severity of tobacco dependence (Tables 3 and 4).

\section{Therapeutic habits}

In line with the modern view of nicotine dependence, the majority of subjects identified the need for a complex 
Magdalena Konopko, Przemysław Bieńkowski, Marcin Wojnar, Jerzy Samochowiec, Danuta K. Ryglewicz, Halina Sienkiewicz-Jarosz

Table 5. Therapeutic habits regarding tobacco dependence among neurologists $(\mathrm{N}=\mathrm{no}, \mathrm{Y}=$ yes)

\begin{tabular}{|c|c|}
\hline Item & $\begin{array}{c}\text { Proportion } \\
\text { of neurologists } \\
\text { answering "yes" (\%) }\end{array}$ \\
\hline \multicolumn{2}{|c|}{ Treatment of tobacco dependence requires: } \\
\hline Psychological intervention (N/Y) & 89 \\
\hline Social intervention $(N / Y)$ & 88 \\
\hline Pharmacological intervention (N/Y) & 64 \\
\hline $\begin{array}{l}\text { Routine use of any anti-smoking } \\
\text { intervention to support smoking } \\
\text { cessation }(N / Y)\end{array}$ & 66 \\
\hline \multicolumn{2}{|l|}{ Quitting cigarette smoking supported by: } \\
\hline Medical advice (N/Y) & 62 \\
\hline $\begin{array}{l}\text { Behavioral intervention according } \\
\text { to the } 5 A^{\prime} \text { s scheme }(N / Y)\end{array}$ & 12 \\
\hline Pharmacotherapy (N/Y) & 11 \\
\hline $\begin{array}{l}\text { Nicotine replacement } \\
\text { therapy }(N / Y)\end{array}$ & 6 \\
\hline Cytisine (N/Y) & 6 \\
\hline Bupropione (N/Y) & 3 \\
\hline Varenicline (N/Y) & 0 \\
\hline Other medications (N/Y) & 3 \\
\hline Acupuncture $(N / Y)$ & 3 \\
\hline Hypnosis (N/Y) & 1 \\
\hline Homeopathy $(N / Y)$ & 0 \\
\hline Other $(\mathrm{N} / \mathrm{Y})$ & 1 \\
\hline
\end{tabular}

therapeutic approach to smoking cessation (Table 5). Two thirds of physicians routinely used any anti-smoking intervention. In contrast, only a small proportion of subjects (12\%) used the recommended 5'A model of behavioral intervention and EBM-based pharmacotherapy (11\%).

Only small subgroups of physicians confirmed the use of alternative methods for smoking cessation (3\% acupuncture, $1 \%$ hypnosis).

\section{Educational needs}

Only $4 \%$ of study subjects perceived their competences in the management of nicotine dependence as "good" or "very good". The vast majority of subjects (80\%) did not try to improve their professional skills in this area. On the other hand, a significant proportion (75\%) of neurologists assessed their educational needs as "moderate" or "higher than moderate" (Tables 5 and 6).

\section{DISCUSSION}

Cigarette smoking is widely recognized as one of ten most important risk factors contributing to first-in-a-lifetime or recurrent stroke $[1,2,24]$. Giving the above, surprisingly little effort has been devoted to analyzing anti-smoking practices among European, including Polish, neurologists.
Table 6. Self-assessed competences and educational needs regarding cigarette smoking and tobacco dependence among neurologists

\begin{tabular}{|l|l|}
\hline Item & Proportion of neurologists (\%) \\
\hline
\end{tabular}

I assess my competences regarding diagnosis and treatment of tobacco dependence as:

\begin{tabular}{l|c|}
\hline Very poor & 14 \\
\hline Poor & 42 \\
\hline Average & 40 \\
\hline Good & 4 \\
\hline Very good & 0 \\
\hline
\end{tabular}

Do you try to increase your competences regarding diagnosis and treatment of tobacco dependence?

\begin{tabular}{l|l}
\hline No & 80 \\
\hline Yes & 20 \\
\hline
\end{tabular}

I assess my educational needs regarding diagnosis and treatment of tobacco dependence as:

\begin{tabular}{l|c}
\hline Very small & 5 \\
\hline Small & 17 \\
\hline Moderate & 47 \\
\hline Significant & 20 \\
\hline Enormous & 8 \\
\hline
\end{tabular}

To the best of our knowledge, the present study is the first comprehensive attempt to assess the perception of smoking-associated health risks and smoking mechanisms, EBM-based diagnostic and therapeutic habits as well as the educational needs of neurologists in this geographical area.

In general, our results show good awareness of smoking-related health risks and good knowledge of the complex etiology of nicotine dependence [2]. The percentage of neurologists conforming to EBM-based anti-smoking practices decreased with complexity of diagnostic and therapeutic procedures. Although two-thirds of neurologists confirmed asking about and documenting the smoking status of their patients, only about one-tenth confirmed using structured anti-smoking interventions and recommending pharmacotherapy $[12,20,23,25]$. In line with the above, seventy five percent of the study group identified their educational needs in this area as average or higher.

Diagnosis of nicotine dependence and the assessment of its severity is a starting point towards efficacious interventions aimed at supporting smoking cessation [12, 20,23 ]. As much as $50 \%$ of the study group declared their routine assessment of the severity of nicotine dependence. Only one fifth of the group formally diagnosed tobacco dependence with the aid of ICD-10 criteria [22]. To the best of our knowledge, the use of ICD-10 or other recommended criteria of nicotine dependence by neurologists has not yet been described. The low percentage of study participants using recommended diagnostic tools, including the ICD-10 criteria, was associated with a relatively low per- 
centage of neurologists using EBM-based therapeutic interventions [12, 20, 23]. Medical advice was the mostpopular therapeutic practice, declared by $62 \%$ of respondents. Our findings are in line with a report by van Schaik et al., who have shown that $88 \%$ of Dutch neurologists routinely discuss smoking cessation as a non-pharmacological treatment of transient ischemic attack (TIA) and stroke [17]. These numbers tend to be higher than those reported for other groups of physicians. For example Frisignelli et al. found that only $45 \%$ of Italian cardiologists routinely advise their patients to stop smoking [26].

The picture is less optimistic considering the use of the structured behavioral interventions supported by EBM guidelines. Only one-tenth of our respondents confirmed using more complex behavioral interventions. The latter number is considerably lower than that observed among Hungarian (25.0\%) and Dutch general practitioners (32.5\%), and Dutch cardiologists (25.0\%) and lung physicians $(26.9 \%)[27,28]$.

The low percentage of neurologists using pharmacotherapy is not surprising. Physicians in other countries are similarly reluctant to use anti-smoking medications. For example, Sipos et al., have showed that only $2 \%$ of Hungarian general practitioners used any anti-smoking medications [27]. Other studies have also indicated that physicians do not routinely prescribe EBM-based antismoking pharmacotherapy [29, 30]. Only $7.6-9.7 \%$ of patients received a prescription for cessation medication during office-based physician visits. There are several possible explanations of the present and previous observations, including a lack of knowledge and/or lack of reimbursement of anti-smoking drugs.

Although health professionals are expected to know how harmful smoking is, and are also expected to be role models for their patients [31], the prevalence of smoking among health professionals is still relatively high in many countries [13]. In the present study, as many as $34 \%$ of neurologists surveyed declared smoking, now or in the past. This figure is alarming because such a proportion of smokers exceed the data for the general population (27\% in the GATS study) [32]. As a matter of fact, in a survey by Ficarra $e t$ al., the prevalence of smoking among health professionals in Italy was $44 \%$ [33]. The data is more consoling in the US, Australia and UK (with smoking rates of less than 10\%), and still worrying in France and Japan (with smoking prevalence rates among physicians of more than 25\%) or developing countries like China, Bosnia/Herzegovina, Turkey and India (with smoking prevalence rates among male physicians as high as 50\%) [34], or countries like the Philippines (with prevalence as high as 63\%) and Mexico (62\%) [35]. One might expect that physicians, having had an adequate medical education and high awareness of smoking-related health harm, and having more professional skills than the general public, should be more reluctant to smoke. This problem may be more complicated and needs further studies on bigger groups of respondents, perhaps conducted with the help of medical specialists' associations.

Last but not least, the neurologists recruited to the study declared a willingness to improve their professional skills in diagnosing and treating nicotine dependence. This observation indicates that more efforts are needed to offer neurologists educational activities aimed at improving their skills in smoking cessation interventions. The present study provides a basis for development of a training platform designed specifically to address the educational needs of neurologists, including those working in stroke units. It may also help to coordinate future educational programs addressed to Polish neurologists, with the same activities currently offered to primary care physicians. It is possible that coordinated approaches to cigarette smoking and combining hospital-based and primary care interventions may increase abstinence rates and reduce smoking-related harm in neurological patients, including stroke survivors [36].

\section{Limitations}

The present study has several limitations that should be noted. Only about 100 neurologists were recruited, hence the results may not be fully generalizable to all neurologists or to other physicians. Moreover, the data was based on self-reports which were not confirmed by other source of information (e.g. medical records).

The results of the present study may show a more optimistic picture than the real-life situation. Most subjects completing the study questionnaire were neurologists working in secondary or tertiary care hospitals with stroke units, localized in towns with more than 100,000 inhabitants. Moreover, the subjects recruited to the study voluntarily participated in post-graduate courses supported by the Polish Neurological Society and were willing to complete a questionnaire on their clinical knowledge and practice. Hence, one may consider the present results as reflecting the diagnostic and therapeutic habits of a more competent subpopulation of Polish neurologists.

Although the data were gathered in 2015 , we should not expect much improvement in the diagnostic and therapeutic practices, as any publicly supported approach to the anti-smoking education of Polish neurologists has not yet been introduced.

\section{CONCLUSIONS}

The present results tend to indicate that Polish neurologists may not play an adequate role in helping patients to reduce cigarette smoking and in treating their tobacco dependence. The study may be a starting point for the development of targeted training programs improving professional skills of neurologists in this therapeutic area. 


\section{Conflict of interest/Konflikt interesu}

Absent./Nie występuje.

\section{Financial support/Finansowanie}

The study was supported by Institute of Psychiatry and Neurology.

\section{References/Piśmiennictwo}

1. Kelly-Hayes M. Influence of age and health behaviors on stroke risk: lessons from longitudinal studies. J Am Geriatr Soc 2010; 58 Suppl 2: S325-S328.

2. Shah RS, Cole JW. Smoking and stroke: the more you smoke the more you stroke. Expert Rev Cardiovasc Ther 2010; 8: 917-932.

3. Sienkiewicz-Jarosz H, Zatorski P, Ryglewicz D, Bienkowski P. Reasons for quitting smoking in patients with first-ever ischemic stroke. Eur Addict Res 2012; 18: 275-278.

4. Suñer-Soler R, Grau A, Gras ME, Font-Mayolas S, Silva Y, Dávalos A, et al. Smoking cessation 1 year poststroke and damage to the insular cortex. Stroke 2012; 43: 131-136.

5. Polakowska M, Piotrowski W, Tykarski A, Drygas W, Wyrzykowski B, Pajak A, et al. Addiction to tobacco smoking in the Polish population. Results of the WOBASZ program. Kardiol Pol 2005; 63 (6 Suppl 4): S626-S631.

6. Twardella D, Loew M, Rothenbacher D, Stegmaier C, Ziegler H, Brenner $\mathrm{H}$. The diagnosis of a smoking-related disease is a prominent trigger for smoking cessation in a retrospective cohort study. J Clin Epidemiol 2006; 59: 82-89.

7. Rigotti NA, Munafo MR, Stead LF. Interventions for smoking cessation in hospitalised patients. Cochrane Database Syst Rev 2007; 3: CD001837.

8. Bienkowski P, Zatorski P, Glebicka A, Scinska A, Kurkowska-Jastrzebska I, Restel M, et al. Readiness visual analog scale: a simple way to predict post-stroke smoking behavior. Int J Environ Res Public Health 2015; 12: 9536-9541.

9. Orleans CT, Alper J. Helping addicted smokers quit: the foundation's tobacco cessation programs. In: Isaacs SL, Knickman JR (eds.). To Improve Health and Health Care. Vol. VI. Princeton, NJ: Robert Wood Johnson Foundation; 2003, pp. 125-148.

10. Cahill K, Stevens S, Perera R, Lancaster T. Pharmacological interventions for smoking cessation: an overview and network meta-analysis. Cochrane Database Syst Rev 2013; 5: CD009329.

11. Steliga MA. Smoking cessation in clinical practice: how to get patients to stop. Semin Thorac Cardiovasc Surg 2018; 30: 87-91.

12. Bangalore S, Schwamm L, Smith EE, Singh IM, Liang L, Fonarow GC, Bhatt DL. Get with the Guidelines-Stroke Steering Committee and Investigators. Secondary prevention after ischemic stroke or transient ischemic attack. Am J Med 2014; 127: 728-738.

13. Jiménez-Ruiz CA, Riesco Miranda JA, Ramos Pinedo A, de Higes Martinez E, Marquez FL, Palomo Cobos L, et al. Prevalence of and attitudes towards smoking among spanish health professionals. Respiration 2015; 90: 474-480.

14. Solano Reina S, Jiménez Ruiz CA, de Higes Martinez E, Garcia Rueda M, Callejas González FJ, de Granda Orive JI, et al. Prevalence, knowledge and attitudes towards smoking among SEPAR members. Arch Bronconeumol 2016; 52: 605-610.

15. Dülger S, Doğan C, Dikiş ÖŞ, Yıldırım E, Tapan U, Özmen İ, et al. Analysis of the role of physicians in the cessation of cigarette smoking based on medical specialization. Clinics (Sao Paulo) 2018; 73: e347.

16. Ovbiagele B, Drogan O, Koroshetz WJ, Fayad P, Saver JL. Outpatient practice patterns after stroke hospitalization among neurologists. Stroke 2008; 39: 1850-1854.

17. van Schaik SM, de Vries BS, Weinstein HC, Visser MC, Van den Berg-Vos RM. Practice variation in long-term secondary stroke prevention in The Netherlands. J Stroke Cerebrovasc Dis 2015; 24: 566-572.

18. Wray JM, Funderburk JS, Acker JD, Wray LO, Maisto SA. A meta-analysis of brief tobacco interventions for use in integrated primary care. Nicotine Tob Res 2018; 20: 1418-1426.

19. Lackland DT, Roccella EJ, Deutsch AF, Fornage M, George MG, Howard G, et al.; American Heart Association Stroke Council; Council on Cardiovascular and Stroke Nursing; Council on Quality of Care and Outcomes Research; Council on Functional Genomics and Translational Biology. Factors influencing the decline in stroke mortality: a statement from the American Heart Association/American Stroke Association. Stroke 2014; 45: 315-353.

20. Anderson JE, Jorenby DE, Scott WJ, Fiore MC. Treating tobacco use and dependence: an evidence-based clinical practice guideline for tobacco cessation. Chest 2002; 121: 932-941.

21. Heatherton TF, Kozlowski LT, Frecker RC, Fagerström KO. The Fagerström Test for nicotine dependence: a revision of the Fagerström Tolerance Questionnaire. Br J Addict 1991; 86: 1119-1127.

22. https://icd.who.int/browse10/2016/en\#/XX.

23. Fiore MC, Baker TB. Clinical practice. Treating smokers in the health care setting. N Engl J Med 2011; 365: 1222 1231.

24. O’Donnell MJ, Xavier D, Liu L, Zhang H, Chin SL, Rao-Melacini P, et al.; INTERSTROKE investigators. Risk factors for ischaemic and intracerebral haemorrhagic stroke in 22 countries (the INTERSTROKE study): a casecontrol study. Lancet 2010; 376: 112-123. 
25. Picciotto MR, Mineur YS. Molecules and circuits involved in nicotine addiction: the many faces of smoking. Neuropharmacology 2014; 76 Pt B: 545-553.

26. Frisinghelli A, Cesana F, Clavario P, Mureddu GF, Temporelli PL, Cherubini A, et al. Italian cardiologists and tobacco smoking. A survey on the prevalence and knowledge of smoking and strategies for smoking cessation in a cohort of Italian cardiologists. G Ital Cardiol (Rome) 2015; 16: 426-432.

27. Sipos V, Pálinkás A, Kovács N, Csenteri KO, Vincze F, Szőllősi JG, et al. Smoking cessation support for regular smokers in Hungarian primary care: a nationwide representative cross-sectional study. BMJ Open 2018; 8: e018932.

28. Kotz D, Wagena EJ, Wesseling G. Smoking cessation practices of Dutch general practitioners, cardiologists, and lung physicians. Respir Med 2007; 101: 568-573.

29. Thorndike AN, Rigotti NA, Stafford RS, Singer DE. National patterns in the treatment of smokers by physicians. JAMA 1998; 279: 604-608.

30. Borum ML. Impact of two ambulatory care training programs on smoking-cessation activities. South Med J 1999; 92: $977-980$.

31. WHO. The Role of Health Professionals in Tobacco Control. Geneva: WHO; 2005.

32. Włodarczyk A, Raciborski F, Opoczyńska D, Samoliński B; GATS PWG. Daily tobacco smoking patterns in rural and urban areas of Poland - the results of the GATS study. Ann Agric Environ Med 2013; 20: 588-594.

33. Ficarra MG, Gualano MR, Capizzi S, Siliquini R, Liguori G, Manzoli L, et al. Tobacco use prevalence, knowledge and attitudes among Italian hospital healthcare professionals. Eur J Public Health 2011; 21: 29-34.

34. Cattaruzza MS, West R. Why do doctors and medical students smoke when they must know how harmful it is? Eur J Public Health 2013; 23: 188-189.

35. Tobacco or health: a global status report. Geneva: WHO; 1997.

36. Chen J, Li S, Zheng K, Wang H, Xie Y, Xu P, et al. Impact of smoking status on stroke recurrence. J Am Heart Assoc 2019; 8: e011696. 